\title{
Saving and investment causality: implications for financial integration in transition countries of Eastern Europe
}

\author{
Manuchehr Irandoust ${ }^{1}$
}

Published online: 24 July 2017

(C) The Author(s) 2017. This article is an open access publication

\begin{abstract}
Numerous studies have been devoted to the Feldstein-Horioka puzzle. However, no consensus has been reached in the literature. This paper examines the causal relationship between domestic saving and investment rates in six transition economies (Estonia, Latvia, Lithuania, Ukraine, Belarus, and Russian Federation). Theoretically, the presence of any type of causal structure between these two series in a country implies that national capital markets are not open; hence capital flows are impeded. Therefore, the paper employs the bootstrap panel Granger causality approach that accounts for both cross-sectional dependence and slope heterogeneity across countries to determine the causal structure. The findings show that there is a causality between the series, thereby implying that capital is not perfectly mobile internationally in any of the countries under review, but it is more mobile in Estonia, Russian Federation, and Latvia than Lithuania, Belarus, and Ukraine. The underdevelopment of financial markets in these countries as well as the demand for foreign capital to finance domestic investment projects and the lack of adequate economic and financial reforms might have driven these results.
\end{abstract}

Keywords Capital mobility $\cdot$ Saving $\cdot$ Investment $\cdot$ Eastern Europe $\cdot$ Causality

JEL classification $\mathrm{F} 3 \cdot \mathrm{F} 4$

Manuchehr Irandoust

manuchehr.irandoust@hkr.se; manuch.dost@gmail.com

1 School of Business Studies, Department of Economics and Finance, Kristianstad University, 291 39 Kristianstad, Sweden 


\section{Introduction}

This paper examines the causal linkage between saving and investment for six Eastern European countries (Estonia, Latvia, Lithuania, Ukraine, Belarus, and Russian Federation). In their seminal work, Feldstein and Horioka (1980) examined the relationship between saving and investment, and they found saving and investment to be highly positively correlated in 16 OECD countries and suggested that international capital mobility was low in these countries. Therefore, if the capital markets are integrated, domestic investment could be financed by foreign savings, and domestic saving could also seek out higher foreign return, thereby implying a low correlation between saving and investment. In the presence of integration of current financial markets, this result reveals a contradiction, which is currently known as the Feldstein-Horioka puzzle. Many theoretical and empirical studies have attempted to resolve this puzzle in the past three decades.

On the one hand, previous studies have confirmed the Feldstein and Horioka findings using a variety of approaches and employing cross-sectional, timeseries and panel data. On the other hand, several papers have challenged Feldstein and Horioka's conclusion. Theoretically, in the short-run a positive saving-investment correlation may arise, despite capital being perfectly mobile across national borders, because of country-size (Harberger 1980; Murphy 1984; Baxter and Crucini 1993; Bahmani-Oskooee and Chakrabarti 2005), commonness in technological or productivity shocks (Rasin 1993; Glick and Rogoff 1995; Eiriksson 2011), non-traded goods (Frankel 1986; Dooley et al. 1987), current account targeting (Summers 1982), endogenous fiscal policy (Levy 1995), international trading costs (Backus et al. 1992; Obstfeld and Rogoff 2000), long-run solvency constraint (Coakley et al. 1996), financial frictions (Bai and Zhang 2010), common deflator (Chu 2012) and long-run risk component in the shock process (Chang and Smith 2014).

Nonetheless, most previous studies are subject to criticism. The cross-section studies in literature on the saving-investment relationship have several limitations which are well-known (eg., Sinn 1992). In the case of time-series studies, inferences about the existence of cointegration suffer from well-known power deficiencies and it has been argued that the saving-investment association captures some degree of international capital mobility so that it reflects a systemic property because capital mobility in one country must imply mobility in at least one other country so that the notion of measuring capital mobility country by country is somewhat anomalous (Feldstein and Bachetta 1991).

The panel cointegration approach adopted in many studies also has some deficiencies which stem from stationarity problems, cross-sectional dependence and slope homogeneity assumptions. The panel cointegration approach adopted in this paper circumvent these problems by simultaneously allowing for country-specific differences in the form of unobserved country effects unlike cross-country studies and combining information from the time series dimension with that obtained from the cross section of units. Furthermore, it has two important advantages. First, it is not required to test the unit root and cointegration (i.e. the variables are used in their levels, without any stationarity 
conditions). Second, additional panel information can also be obtained given the contemporaneous correlations across countries (i.e. the equations denote a Seemingly Unrelated Regressions system- SUR system). To the best of the author's knowledge, this paper is the first to apply the bootstrap panel Granger causality approach to examine the relationship between saving and investment.

The remainder of this paper is organized as follows: Section 2 reviews some stylized facts about economic and financial structure of the sample countries. Section 3 provides empirical framework, data, and methodology. Section 4 presents the empirical results. Section 5 offers some discussion. Section 6 concludes.

\section{Some stylized facts}

\subsection{Baltic states ${ }^{1}$}

After regaining independence in 1991, the governments of the Baltics started comprehensive programs of economic and political reform. In order to achieve economic growth and improve living standards, the Baltics made a rapid shift from a planned economy to an open market system by establishing the relevant legal framework and economic institutions. The priority was given to the liberalization of prices, external trade, and a stable exchange system, as well as to the privatization of small and medium-size enterprises. The Baltic countries liberalized their capital accounts relatively quickly compared to other transition countries. The economic situation in early 1990s was very difficult as real output contracted sharply and prices soared. The economic and political collapse of the Soviet Union created very high inflation that sharply eroded living standards. The trade and financial links between the independent Baltic States and other countries were disrupted, generating a number of demand and supply shocks such as major adjustment in the relative prices of tradable goods, loss of traditional export markets in the East, as well as dis-functioning of payment and monetary arrangements.

Under these circumstances, the Baltic States found little scope for a gradualist approach in policy response. The Baltics introduced their own currencies with fixed exchange rates relatively early during transition because it was believed that fixed exchange rate arrangements were more suited in light of lack of accumulated experience with independent central banking. Fixed exchange rate regimes, supported by tight fiscal policies and structural reforms, helped to restore macroeconomic stability and contain inflation in the region. Thereafter, output stabilized relatively rapidly and economic recovery began in Estonia, Latvia, and Lithuania in 1994 and GDP growth turned positive in Estonia, Lithuania, and Latvia. During 1995-1998 average GDP growth ranged from $6.6 \%$ in Estonia to $4 \%$ in Latvia. Despite the liberalization of most prices, inflation was quickly brought under control. CPI inflation dropped from almost $1000 \%$ in 1992 to below 30\% in all three countries by 1996 and declined to a

\footnotetext{
${ }^{1}$ This part is mainly based on European Commission (2009, 2010, 2015), Grigonyte (2010), and UNCTAD (2016).
} 
single digit by 1998. On the other hand, the current account deficit started to increase rapidly from 1994, and amounted to 5.5\% of GDP in Latvia, $10 \%$ in Lithuania, and 11\% in Estonia by 1997.

The privatization-related FDI inflows covered a part of the domestic savinginvestment gap, e.g., in 1993-1997 average annual FDI inflows amounted to $6 \%$ of GDP in Estonia and Latvia, but only 2\% in Lithuania. In Estonia, most small enterprises were privatized by heavily on vouchers but also used tenders for strategic investors. Furthermore, improved bankruptcy procedures and modernized legal and regulatory framework also played an important role in reforming the economies. Estonia was slightly ahead of the other two Baltics in this area. Compared to other transition economies, the Baltics made faster progress in reducing the role of the state in the economy and creating a business-friendly environment. Tight fiscal policy was a very important factor contributing to the stabilization and reform process. The level of government spending and public debt was lower in the Baltics than in the EU-15 and other transition economies.

As a result of the prudent fiscal policies in the Baltics the debt remained very low by international standards. In 1995, Estonian debt equaled 9\% of GDP and declined to $3.5 \%$ in 2007. Latvian debt remained rather low until 2007 , close to $9 \%$ of GDP. In Lithuania, the debt-to-GDP ratio was on an increasing trend until 2000 but started to decline afterwards mainly due to strong GDP growth and in 2007 it was equal to $17 \%$ of GDP. The first real economic shock for the Baltic economies after the collapse of the planned economy took place with the Russian financial crisis in 1998. The crisis caused a recession in the Baltic states and this was accompanied by a collapse in trade and losses in the financial system. On the real side, Baltic exporters, which were dependent on Russian markets, were dealing with a very sharp deterioration in terms of trade following the devaluation of the rouble by more than 70\% during 1998-1999, while imported Russian commodities were linked to the U.S. dollar.

Although Russia's share of the Baltics' external trade had declined even before the crisis, it remained at around one-fifth of exports for Estonia and Latvia, and around one third in Lithuania. In 1999, economic growth turned negative in Estonia and Lithuania, and dropped sharply in Latvia. In all three countries, the budget surpluses also turned into deficits. In parallel with the trade crisis, the financial sector faced loan losses from their exposures to companies which were dependent on the Russian market. The adjustment phase, which started already before the financial turmoil began to unfold in 2008, was considerably intensified by global developments. In 2009, GDP decreased by almost $13 \%$ in Estonia, $18.0 \%$ in Latvia and Lithuania. However, GDP growth rates for the three Baltic countries remain at around 3\% per year during 20132015.

However, FDI inflows to the Baltic countries were attracted by different factors during the decade of economic transition. On the one hand, FDI was mainly driven by the availability of relatively low-cost resources as the privatization process created business opportunities for foreign investors in the manufacturing sector. On the other hand, an underdeveloped services sector opened up scope for horizontal FDI. Particularly, the privatization of public 
utilities and liberalization of the banking sector attracted significant FDI inflows. At the same time, the Baltic states' convenient geographical location, located between the EU, Russia and the Commonwealth of Independent States (CIS) countries, as well as EU membership attracted efficiency-seeking FDI. The successful structural reforms and a relatively stable macroeconomic environment were the main reasons for attracting FDI to the Baltics.

FDI into Estonia amounted to $\$ 2799$ million in 2005, \$1565 million in 2012, \$546 million in 2013, and \$208 million in 2015. In Latvia, FDI was \$2324 million in 2007, \$1453 million in 2011, \$1109 million in 2012, and $\$ 643$ million in 2015. FDI into Lithuania amounted to \$2015 million, \$1446 million, $\$ 469$ million, and $\$ 863$ million in 2007, 2011, 2013, and 2015, respectively. On average, FDI inflows during the period 1993-2014 were $7.24 \%$ of GDP in Estonia, $3.87 \%$ in Latvia, and $2.91 \%$ in Lithuania. Estonia has outperformed the other two countries since 1997, when it overtook Latvia, and especially since EU accession. This was largely due to the establishment of Nordic banks in Estonia. Analyzing the various components of FDI for the three Baltic countries over the last decades, it shows that FDI inflows in Latvia and Lithuania have been dominated by equity capital, (mostly in the form of acquisitions and green field investment), while Estonia has received on average a much higher share of reinvested earnings probably due to the Estonian corporate tax system which was reformed in 2000. The tax rate on reinvested earnings was reduced to zero, whereas the tax on corporate income was set to $21 \%$ in order to support the accumulation of domestically-generated capital.

Generally speaking, all Baltic countries have been quite successful with respect to structural reforms, Estonia has moved not only faster than its neighbors with the timing and the implementation of reforms but also carried out more reforms in the areas of enterprise and competition policy than Latvia and Lithuania. The two latter types of reform would reduce the abuse of market power and improve effective corporate control exercised through domestic financial institutions and markets, thereby supporting market-driven restructuring.

\subsection{Russian Federation, Belarus, and Ukraine ${ }^{2}$}

\section{Ukraine}

Shortly after independence in August 1991, the Ukrainian Government liberalized most prices and created a legal framework for privatization, but widespread resistance to reform within the government and the legislature hindered reform efforts and led to some backtracking. Consequently, output by 1999 had fallen to less than $40 \%$ of the 1991 level. Sharply declining output, lack of access to financial markets, and massive monetary expansion to finance government spending resulted in hyperinflation. Thus, in 1996 the Ukrainian central bank replaced the old currency, the karbovanets, with the

\footnotetext{
${ }^{2}$ This part is mainly based on The Economist (2014), KPMG (2011, 2013), Mehmet Ogutcu (2002), Cooper (2009), and UNCTAD (2016).
} 
hryvnia and attempted to keep it stable in relation to the dollar. The currency continued to be unstable through the late 1990s.

Once Russia started to raise energy prices (in the aftermath of gradual adjustment of its own relative price structure), Ukraine was badly hit because of the high-energy intensity of Ukraine's economy (high percentage of the metal industry for instance). This made the Ukrainian economy vulnerable to external shocks. The IMF encouraged Ukraine to quicken the pace and scope of reforms to promote economic growth. Ukrainian Government officials eliminated most tax and customs privileges in 2005 budget law, brought more economic activity out of Ukraine's large shadow economy, but more improvements were needed, including fighting corruption, developing capital markets, and improving the legislative framework. The economy contracted around $15 \%$ in 2009 , among the worst economic performances in the world. The government issued short-term debt at interest rates as high as $15 \%$ and many analysts were worried that the country will soon default on its debt.

After the global crisis, and as the euro crisis intensified, Ukraine suffered from a drought in capital flows which put strong downward pressure on the hryvnia. Protecting the currency drained the central bank's reserves, which dropped from a high of $\$ 40$ billion in 2011 to about $\$ 12$ billion in 2014 . Then, the central bank admitted defeat and let the currency float. Currency depreciation was an economic headache for Ukraine in the short term. About half of its public debt was in foreign currencies: as the hrvynia lost value, Ukraine's debt burden rose. Moreover, Ukraine was badly hit by the financial crisis which resulted in GDP to fall by $15 \%$ in 2009. In 2010, the IMF agreed to loan Ukraine $\$ 15$ billion. The IMF ended up freezing the deal in 2011 after Kiev failed to touch the costly subsidies.

Progressively lowering the rate of corporation tax has also weakened the state's finances. Corruption, poor governance, interstate conflict, and political situation are other major problems. The Ukrainian shadow economy is one of the biggest in the world-at around $50 \%$ of GDP, according to IMF. Businesses operating underground tend not to pay taxes, further depriving the government of funds. Ukraine needed to find about $\$ 25$ billion in 2014 to finance its large current-account deficit and to meet foreign creditors. FDI was $\$ 267$ million, \$10,913 million, \$8401 million, \$4499 million, \$410 million, and \$2961 million in 1995, 2008, 2012, 2013, 2014, and 2015, respectively. However, the level of reforms in Ukraine with respect to privatization, banking reforms, and infrastructure have been half-hearted.

\subsubsection{Russian Federation}

The first seven years of Russia's transition from the Soviet central planned economy (1991-1998) were not easy. During the period, Russia lost 30\% of its GDP and also suffered very high rates of inflation- over 2000\% in 1992 and over $800 \%$ in 1993- before it declined to more tolerable levels of around $20 \%$ by the end of the 1990s. Nevertheless, the country's fixed exchange rate regime together with its fragile fiscal position appeared to be unsustainable when the international markets got affected by spillover effects of financial distress 
elsewhere in the world. In the course of 1998, the outbreak of a severe banking, currency and sovereign debt crisis could not be prevented. This led to a significant decrease in the value of the ruble, eventually forcing the Russian government to devalue the ruble in 1998. Russia did not perform much better in the foreign sector and FDI flows were not significant given the size and needs of the Russian economy. The cumulative figure for FDI in Russia from 1991 through the end of 2001 shows $\$ 18.2$ billion, or only 5\% of domestic fixed capital formation.

Furthermore, Russia was incurring serious capital flight- some $\$ 150$ billion worth between 1992 and 1999. During the period, the Russian government had large budget deficits that reached as high as $9.8 \%$ of GDP, forcing the government to finance debt at very high interest rates. Russia's economic problems intensified by the financial crisis in 1998. The crisis led to the demise of many Russian banks which had held government debt. The crisis caused: Russian interest rates soared aimed inconsistent macroeconomic policy which triggered the crises. Hence, prices on the Russian stock market plummeted; and the value of the Russian ruble sank. During 1998, the ruble lost $60 \%$ of its (nominal) value in terms of the dollar. In addition, foreign reserves decreased substantially during that time. The reserves, including gold, dropped from $\$ 18.4$ billion to $\$ 12.5$ billion, and real GDP declined $4.9 \%$ in 1998 .

Russian economy was vulnerable because of more fundamental problems related to the economic policy and economic structure. These included the failure to institute tax reform, property rights, and bankruptcy laws and procedures. Later on, Russia made some attempts to perform economic reform during this period by moving from the centrally planned economic system and introducing market prices for most goods and services. This made the Russian ruble convertible for trade transactions, and the economy was opened to foreign trade and investment.

Russia also lifted its restrictions on capital inflows. After 2005, FDI inflows grew exponentially, due to investments in newly liberalized sectors. After reaching record heights in 2008, the financial crisis led to a collapse in FDI, as the global economy entered into a recession. Since the severe drop in 2009 , FDI has recovered partially, reaching USD 30188 million in 2012, USD 53397 million in 2013, USD 29152 million in 2014, and USD 9825 million in 2015. Foreign investors remain motivated by the continued strong growth of the consumer market and affordable labor costs, together with productivity gains. They also continue to be attracted by high returns in energy and other naturalresource related projects. During 2007-2011, the US was a leading investor in Russia with 122 projects, corresponding to $16 \%$ of total projects. The second largest investor was Germany, with 99 projects in different sectors. In 2011, investments from the Netherlands accounted for $12 \%$ of total FDI in Russia.

\subsubsection{Belarus}

Since early 2000s, the economic situation in Belarus was characterized by a dynamic economic growth. The annual growth rate of GDP at constant prices over five years through 2008 was around 10\%. On the one hand, as a statedominated economy, with only limited relationships with the world financial 
markets, has been less affected by the severe effects of the financial crisis. On the other hand, a sharp decline in both Russian economic subsidies and foreign trade with Russia stemming from the global crisis has had a significant impact on the Belarusian economy, albeit with some lag. Consequently, in 2009, GDP growth was marginal at $0.2 \%$, while external financing, primarily from the IMF, allowed for keeping the economy stable. The gradual recovery following in 2010 resulted in a substantial increase of wages and the already high level of financing of government programs. As a result, the annual GDP grew by $7.6 \%$ in real terms, which was at the cost of a further increase of the current account deficit and inflationary pressures.

This crisis stemmed from the fact that the authorities kept the de-facto fixed exchange rate regime for too long (and the exchange rate remained too strong). As the Russian ruble floated much more freely and Russia reduced the aforementioned forms of subsidies (and some other) to Belarus the country's balance of payments came under pressure. Significant control and influence of the state on the economy were the main prerequisites of the crisis. The authorities used growth-promoting policies, expansionary credit practices and broadly applied generous financing of various state programs. This was together with a significant boost of wages and an increase in demand for value-added, primarily imported goods. Thus, the crisis emerged from devaluation expectations in 2011 as a result of diminishing foreign exchange reserves of the National Bank.

To tackle the situation, the government devalued the currency to the basket of currencies by more than $50 \%$ ( $56 \%$ to USD). However, this was believed to be a late and inadequate response, as the National Bank's foreign reserves were not sufficient to provide effective support to the market demand of the hard currency even after the devaluation. To create the country's foreign exchange reserves, the authorities were actively looking for external funding, which was most likely to come from the foreign anti-crisis organizations and massive privatization. The results of the crisis generated a significant effect on all sectors of the economy lacking funds in foreign currencies to pay for imported production inputs and goods. While the Government reported a growth of GDP by $11.1 \%$ in 2011 on an annual basis, CPI for the six months of the year grew by a record $43.8 \%$ since June 2010 .

Belarus has a substantial and relatively well-developed industrial base due to its history as an "assembly plant" in the former Soviet Union (49\% of GDP in 1990). The contribution of added value of industry in GDP amounted to $26.8 \%$ in 2010. In addition, the country has a broad agricultural base and is fully selfsufficient in agricultural production and also provides export opportunities. The Belarusian economy is dominated by state controlled sectors. Privatization talks have been re-activated in 2009 and 2010, partly in response to IMF/ World Bank recommendations, and again in 2011 as an attempt to tackle the crisis.

FDI into the Belarusian economy was relatively moderate through 19902006. Due to the Government's first steps towards liberalizing the economy and the promotion of investment opportunities, in 2007 the Belarusian economy received USD 1.79 billion of net FDI, five times higher than in 2006. In 2008, the country's economy received USD 2150 million in FDI. FDI into Belarus amounted to USD 1877 million in 2009, USD 1393 million in 2010, USD 4002 
million in 2011, USD 1429 million in 2012, USD 2230 million in 2013, USD 1828 million in 2014, and USD 1584 million in 2015. However, FDI in Belarus averaged 314.50 USD million from 2000 until 2016, reaching an alltime high of 2734.30 USD million in the fourth quarter of 2011. A major source of FDI to Belarus in 2010 was Russia (USD 820.4 million or $60.8 \%$ of gross FDI inflow). Significant shares of FDI originated also from Germany, Switzerland, China, and Iran. Equity injections totally USD 111.3 million also went into the banking sector.

\section{Empirical framework, data, and methodology}

Capital mobility is important issue because, in a world with high capital mobility, national governments can follow expansionary fiscal policies without confronting large-scale crowding out implied by these policies. Furthermore, the existence of high capital mobility rules out the constraints imposed by domestic credit markets and money supplies. Thus, monetary policy is rendered much less effective under this condition. The presence of internationally mobile capital also means that capital owners do not bear the full burden of corporate income tax. In a such environment, capital may freely move to a country where the return is higher, i.e., taxes are lower.

The saving-investment approach to capital mobility was first presented by Feldstein and Horioka (1980). It is based on the assumption that, in a world with perfect capital mobility, a country will indicate very little correlation between domestic saving and investment in the long run. If perfect capital mobility does not exist, then differences among the country's investment rates should correspond to differences in its respective saving rates. Thus, by comparing the correlations between domestic saving and investment rates in various countries, one can determine the degree of capital mobility.

However, our study is based upon the same postulated relationships between domestic investment and saving rates; but it is not concerned with assessing the correlation between them. Rather, this study attempts to present further evidence on capital mobility by exploring the causal relationship between saving and investment rates in six eastern European countries. In a world with imperfect capital mobility, changes in saving must create changes in investment and vice versa. Thus, the presence of any form of causal relationship between these two series must be interpreted as an indication that national capital markets are not open; capital flows are hindered; hence there is no financial integration. If, however, no causality is found, one can conclude that the economy is open and capital is mobile (Leachman 1990).

The data are downloaded from the World Bank's World Development Indicators. Given the data availability, the annual data (1995-2014) for the following economies are used: Estonia, Latvia, Lithuania, Ukraine, Belarus, and Russian Federation. These countries were chosen because of the fact that they were economically and politically very dependent on the former Soviet Union and it would be interesting to study their capital markets' progress after their independence. The selection of time period is dictated by the availability of 
data. Investment (INV) is the ratio of gross domestic investment to GDP (I/Y) and saving $(S A V)$ is the ratio of gross domestic saving to GDP (S/Y). Figures 1, 2, 3, 4, 5 and 6 (Appendix 1) illustrates the variables for each country and in Appendix 2, data sources, definition of variables, study period are collected together.

The estimation follows the bootstrap panel Granger causality proposed by Kónya (2006). This approach has two important advantages. First, it is not required to test the unit root and cointegration (i.e. the variables are used in their levels, without any stationarity conditions). Second, additional panel information can also be obtained given the contemporaneous correlations across countries (i.e. the equations denote a Seemingly Unrelated Regressions systemSUR system).

Two steps should be followed before applying the bootstrap panel Granger causality: testing the panel for cross-sectional dependence and testing for cross-country heterogeneity. The first issue implies the transmission of shocks from one variable to others. In other words, all countries in the sample are influenced by globalization and have common economic characteristics. The second issue indicates that a significant economic connection in one country is not necessarily replicated by the others.

A set of three tests is constructed in order to check the cross-sectional dependence assumption: the Breusch and Pagan (1980) cross-sectional dependence $\left(\mathrm{CD}_{\mathrm{BP}}\right)$ test, the Pesaran (2004) cross-sectional dependence $\left(\mathrm{CD}_{\mathrm{P}}\right)$ test, and the Pesaran et al. (2008) bias-adjusted LM test $\left(\mathrm{LM}_{\mathrm{adj}}\right)$. Regarding the countryspecific heterogeneity assumption, the slope homogeneity tests $\left(\bar{\Delta}\right.$ and $\left.\Delta_{\text {adj }}^{-}\right)$of Pesaran and Yamagata (2008) are used (Appendix 3 provides more information about these tests). The Kónya's (2006) approach considers both issues, based on SUR systems estimation and identification of Wald tests with country-specific bootstrap critical values. This procedure allows us to consider all variables in their levels and perform causality output for each country:

$$
\begin{gathered}
S A V_{1, t}=\alpha_{1,1}+\sum_{i=1}^{\operatorname{lm} 1} \beta_{1,1, i} S A V_{1, t-i}+\sum_{i=1}^{\ln 1} \delta_{1,1, i} I N V_{1, t-i}+\varepsilon_{1,1, t}, \\
S A V_{2, t}=\alpha_{1,2}+\sum_{i=1}^{\operatorname{lm} 1} \beta_{1,2, i} S A V_{2, t-i}+\sum_{i=1}^{\ln 1} \delta_{1,2, i} I N V_{2, t-i}+\varepsilon_{1,2, t}, \\
S A V_{N, t}=\alpha_{1, N}+\sum_{i=1}^{\operatorname{lm} 1} \beta_{1, N, i} S A V_{N, t-i}+\sum_{i=1}^{\ln 1} \delta_{1, N, i} I N V_{N, t-i}+\varepsilon_{1, N, t},
\end{gathered}
$$

and

$$
\begin{gathered}
I N V_{1, t}=\alpha_{2,1}+\sum_{i=1}^{l m 2} \beta_{2,1, i} S A V_{1, t-i}+\sum_{i=1}^{\ln 2} \delta_{2,1, i} I N V_{1, t-i}+\varepsilon_{2,1, t}, \\
I N V_{2, t}=\alpha_{2,2}+\sum_{i=1}^{l m 2} \beta_{2,2, i} S A V_{2, t-i}+\sum_{i=1}^{\ln 2} \delta_{2,2, i} I N V_{2, t-i}+\varepsilon_{2,2, t}, \\
I N V_{N, t}=\alpha_{2, N}+\sum_{i=1}^{l m 2} \beta_{2, N, i} S A V_{N, t-i}+\sum_{i=1}^{\ln 2} \delta_{2, N, i} I N V_{N, t-i}+\varepsilon_{2, N, t},
\end{gathered}
$$

In equation systems (1) and (2), $S A V$ is the ratio of gross domestic saving to GDP, $I N V$ denotes the ratio of gross domestic investment to GDP, $N$ is the number of panel members, $t$ is the time period $(t=1, \ldots, T)$, and $i$ is the lag length selected in the system. The common coefficient is $\alpha$, the slopes are $\beta$, and $\delta$, while $\varepsilon$ is the error term. 
To test for Granger causality in this system, alternative causal relations for each country are likely to be found: (i) there is one-way Granger causality from X to Y if not all $\delta_{1, i}$ are zero, but all $\beta_{2, i}$ are zero; (ii) there is one-way Granger causality from $\mathrm{Y}$ to $\mathrm{X}$ if all $\delta_{1, i}$ are zero, but not all $\beta_{2, i}$ are zero; (iii) there is two-way Granger causality between $\mathrm{X}$ and $\mathrm{Y}$ if neither $\delta_{1, I}$ nor $\beta_{2, i}$ are zero; and (iv) there is no Granger causality between $\mathrm{X}$ and $\mathrm{Y}$ if all $\delta_{1, i}$ and $\beta_{2, i}$ are zero. It is also allowed the maximal lags to differ across variables, but the same across equations. In this study, the system is estimated by each possible pair of $l_{m 1}, l_{n 1}, l_{m 2}$, and $l_{n 2}$, and it is assumed that 1 to 4 lags exist. Then the combinations that minimize the Schwarz Bayesian Criterion are chosen.

By inspecting the data, we find that most break dates correspond to major events such as the financial crisis of 1997-1998 and 2007-2008 and the economic downturn of 2001. Due to the existence of these structural breaks, we should incorporate these breaks into our testing model; otherwise, the results will be biased. Since Kónya (2006) cannot allow different break dates into the testing model, we follow the procedure adopted by Tsong and Lee (2011) and Bahmani-Oskooee et al. (2014) to adjust the data as follows:

$$
\hat{y}=y_{t}-\hat{\alpha}-\sum_{l=1}^{m+1} \hat{\theta} D U_{l, t}-\sum_{i=1}^{m+1} \hat{\rho}_{i} D T_{i, t}-\varepsilon_{t},
$$

where, $\hat{y}_{\mathrm{t}}$ (either $S A V$ or $I N V$ ) is adjusted by the effect of possible structural breaks, $y_{t}$ is $S A V$ or $I N V, D U_{\mathrm{t}}$ and $D T_{\mathrm{t}}$ are defined as the following:

$$
\begin{gathered}
D U_{k, t}= \begin{cases}1 & \text { if } T B_{k-1} \prec t \prec T B_{k} \\
0 & \text { otherwise }\end{cases} \\
D T_{k, t}=\left\{\begin{array}{cc}
t-T B_{k-1} & \text { if } T B_{k-1} \prec t \prec T B_{k} \\
0 & \text { otherwise }
\end{array}\right.
\end{gathered}
$$

\section{Estimation results}

Table 1 reports the results of cross-sectional dependence tests $\left(\mathrm{CD}_{\mathrm{BP}}, \mathrm{CD}_{\mathrm{p}}\right.$, and $\left.\mathrm{LM}_{\mathrm{adj}}\right)$ and slope homogeneity tests $\left(\bar{\Delta}\right.$ and $\left.\Delta_{a d j}^{-}\right)$. The first set of tests, for cross-sectional dependence, clearly reveals that the null hypothesis of no cross-sectional dependence is rejected for all significance levels. More precisely, this implies that there is a crosssectional dependence in the case of our sample countries. Any shock in one country is transmitted to others, the SUR system estimator being more appropriate than countryby-country pooled OLS estimator. The second part of the Table shows that the null hypothesis of slope homogeneity is rejected for both tests and for all significance levels. In this case, the economic relationship in one country is not replicated by the others. As 
Table 1 Cross-sectional dependence and slope homogeneity tests

\begin{tabular}{llr}
\hline Method & Test statistics & $p$-value \\
\hline Cross-sectional dependence test & & \\
CD $_{\mathrm{BP}}$ & $98.267^{* * *}$ & 0.0000 \\
$\mathrm{CD}_{\mathrm{P}}$ & $11.235^{* * *}$ & 0.0000 \\
$\mathrm{LM}_{\mathrm{adj}}$ & $16.346^{* * *}$ & 0.0000 \\
Slope homogeneity test & & 0.0000 \\
$\bar{\Delta}$ test & $14.243^{* * *}$ & 0.0000 \\
$\Delta_{\text {adj }}^{-}$test & $10.528^{* * *}$ & \\
\hline
\end{tabular}

$\mathrm{CD}_{\mathrm{BP}}$ test, $\mathrm{CD}_{\mathrm{P}}$ test, and $\mathrm{LM}_{\mathrm{adj}}$ test show the cross-sectional dependence tests of Breusch and Pagan (1980), Pesaran (2004), and Pesaran et al. (2008), respectively $\bar{\Delta}$ test and $\Delta_{a d j}^{-}$test show the slope homogeneity tests proposed by Pesaran and Yamagata (2008)

*** indicate significance for 0.01 levels

there are both cross-sectional dependence and slope heterogeneity, the bootstrap panel Granger causality approach can be applied.

The results of the bootstrap panel Granger causality test are shown in Table 2. The findings show that $S A V$ and $I N V$ are causally related in the countries under review. The bidirectional causality or feedback effect is found in the sample countries. The results indicate that capital is not perfectly mobile internationally in any of the countries, but it is more mobile in Russia, Estonia, and Latvia than Lithuania, Belarus, and Ukraine.

\section{Discussion}

The evidence shows that capital markets of the economies under review are neither perfectly open nor perfectly integrated, but capital is more mobile in Russia, Estonia, and Latvia than Lithuania, Belarus, and Ukraine. Furthermore, perfect capital mobility, like perfect competition, exists as a theoretical ideal which is rather removed from reality. In addition, the causality tests show that although perfect capital mobility is an unrealistic assumption, small open economy models may be appropriate for individual countries where there is no capital control. This evidence here shows the fact that all of the countries exhibiting series dependence and have some kind of capital controls.

The interest differential approach, which in general supports a high degree of capital mobility internationally, examines the mobility of a group of financial assets which are not capital in the true economic sense of the word rather than the stock of existing capital. Therefore, the interest differential approach tests the mobility of the stock of existing capital between country pairs and suggests that the existing capital stock is highly mobile and that financial markets are highly integrated.

On the other hand, changes in saving and investment rates indicate new physical capital and are subject to the real rate of return. This implies that the saving-investment approach tests for the mobility of the flow of new capital which is reflected in the much smaller net flow of capital into or out of an economy. Moreover, the saving-investment approach is a means of testing international equalization of the real rate of interest and integration of national goods markets. Therefore, the saving-investment test results reveal that the flow of new capital is much less mobile than the existing capital stock; 


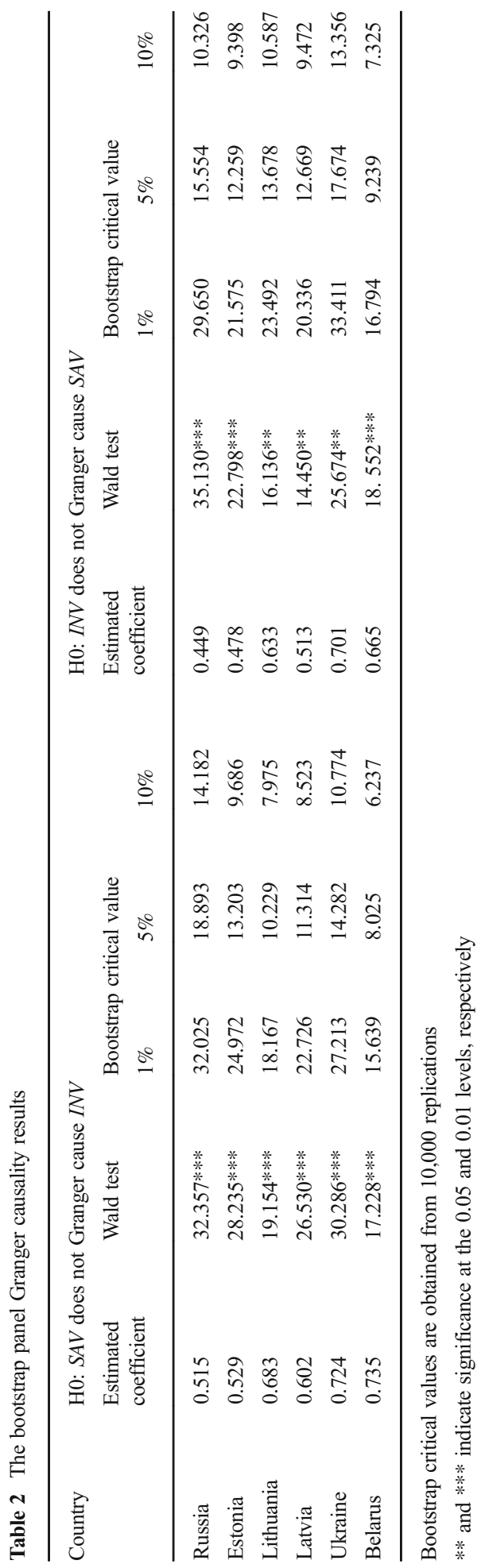


and as a by-product, real rates of return are not equal nor are good's markets integrated across countries.

According to the analysis of saving and investments causality, the eastern European countries under review are not perfectly integrated into the world capital market. However, they could significantly increase the degree of international capital mobility by the removal of capital controls and further barriers that limit the import and export of capital. In order to avoid the side effects of lifting barriers to capital account activity such as crises, an increase in debt, and financial instability, removal of barriers should be coordinated with certain macroeconomic policies. These are: a developed financial sector capable of coping with volatility in capital flows; the steady absence of a substantial capital account deficit; a sufficient level of international reserve assets; a floating exchange rate; and a cautious fiscal policy.

Beside, a low degree of financial integration as a s result of a high value of savings retention, it has also been argued that the finding of a high value of savings retention coefficients also indicates: (i) high political and currency risk of overseas securities holding; (ii) a low degree of human capital mobility; (iii) a solvency constraint by open capital markets; (iv) a lack of consumption smoothing in response to productivity shocks; and (v) effective use of policy instruments by governments in targeting the current account. ${ }^{3}$

\section{Conclusion}

Previous studies of causality and panel cointegration between saving and investment does not consider cross-sectional dependence and slop heterogeneity across countries. On the basis of the bootstrap panel Granger causality test (that accounts for both crosssectional dependence and heterogeneity across countries), one can conclude that for the countries under review (Russian Federation, Estonia, Latvia, Lithuania, Belarus, and Ukraine) in general, changes in the saving rate lead to changes in the investment rate or vice versa. The underdevelopment of financial markets in these countries as well as the demand for foreign capital to finance domestic investment projects and the lack of adequate economic and financial reforms might have driven these results.

The integration of financial markets into the world capital market is important for economic growth in eastern European countries since the access to foreign capital increases the number of investments and entails the transfer of technology through FDI. Financial market integration is furthermore necessary for an efficient monetary policy in an enlarged monetary union, since different degrees of financial market integration cause different reactions on monetary shocks.

Acknowledgements The useful comments of three anonymous referees are really appreciated. Of course, any remaining error is mine.

\footnotetext{
${ }^{3}$ These issues have also been discussed in Bahmani-Oskooee and Chakrabarti (2005), Nell and Santos (2008), and Pelgrin and Schich (2008).
} 


\section{Appendix 1}

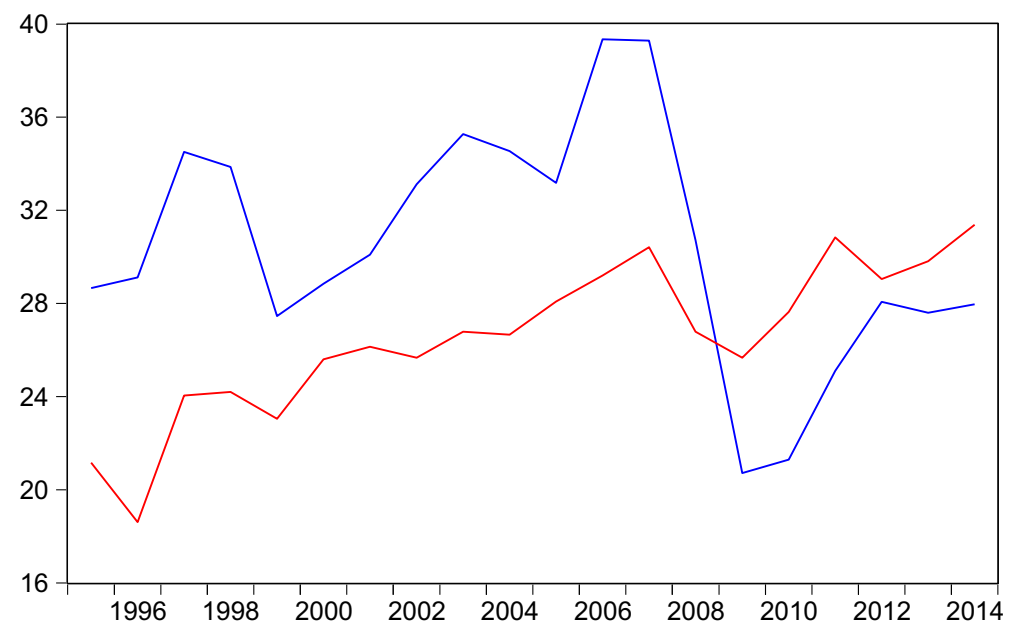

Figure 1: $S / Y$ and $I / Y$ in Estonia

— ESTI — ESTS

Fig. $1 \mathrm{~S} / \mathrm{Y}$ and $\mathrm{I} / \mathrm{Y}$ in Estonia

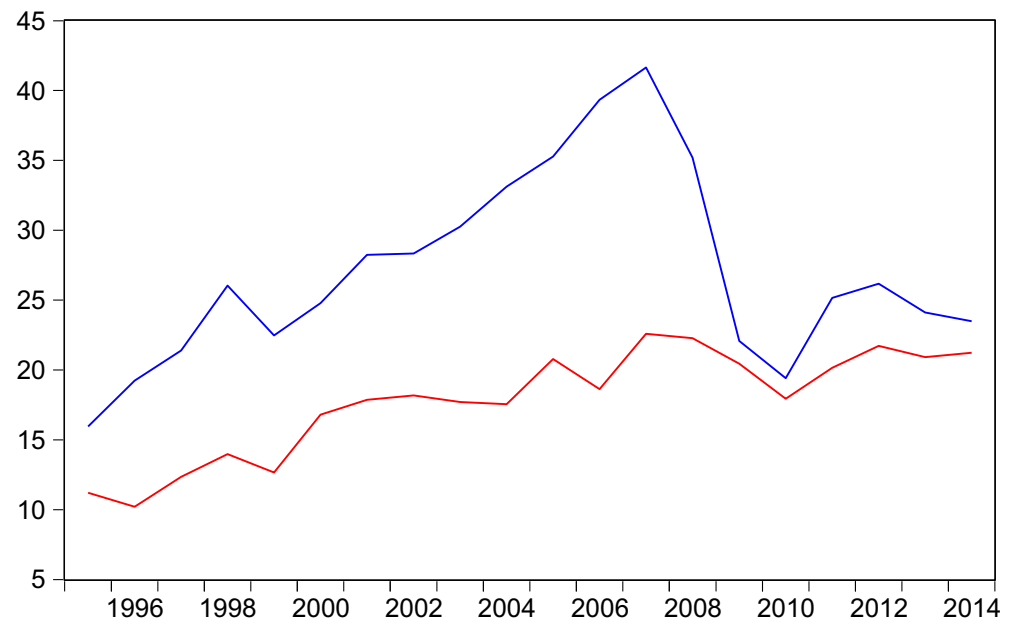

Figure 2: $S / Y$ and $I / Y$ in Latvia

$$
\text { — LVAI — LVAS }
$$

Fig. $2 \mathrm{~S} / \mathrm{Y}$ and $\mathrm{I} / \mathrm{Y}$ in Latvia 


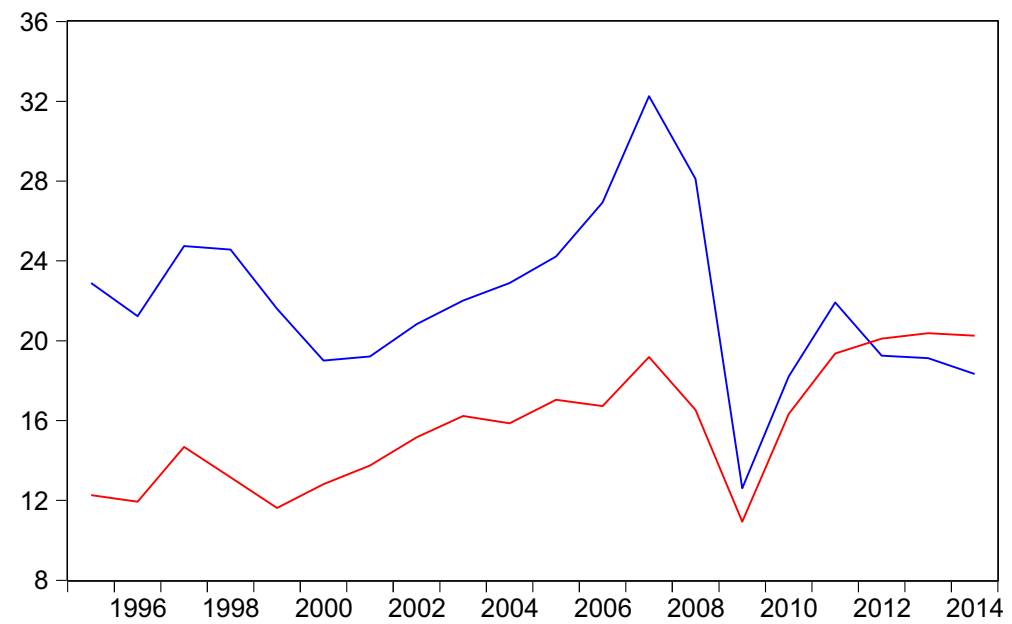

Figure 3: $S / Y$ and $I / Y$ in Lithuania

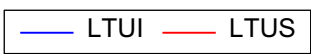

Fig. $3 \mathrm{~S} / \mathrm{Y}$ and $\mathrm{I} / \mathrm{Y}$ in Lithuania

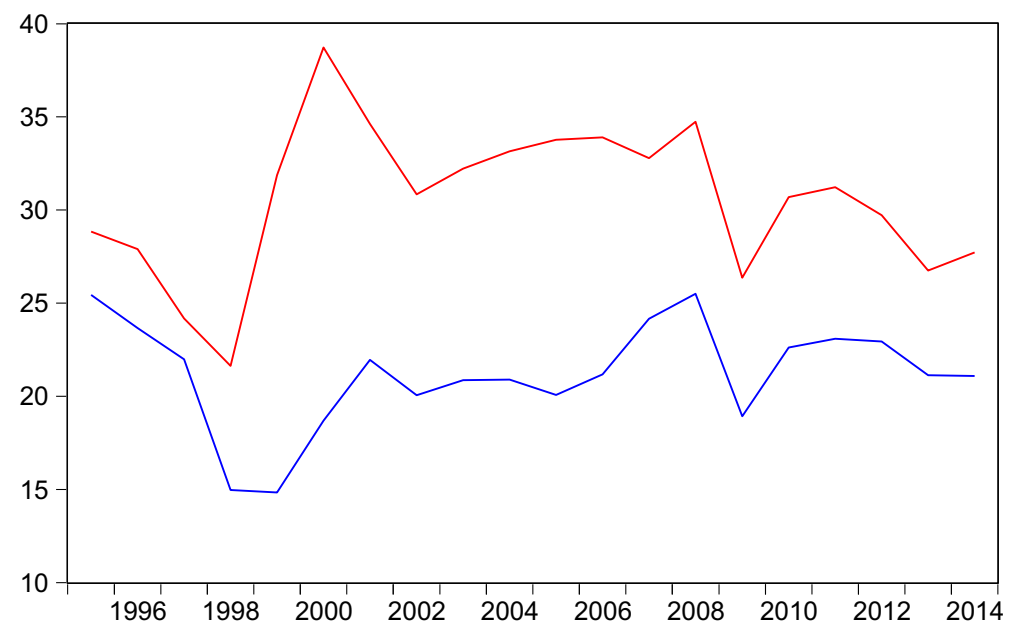

Figure 4: $S / Y$ and $I / Y$ in Russia

$$
\text { — RUSI — RUSS }
$$

Fig. $4 \mathrm{~S} / \mathrm{Y}$ and $\mathrm{I} / \mathrm{Y}$ in Russia 


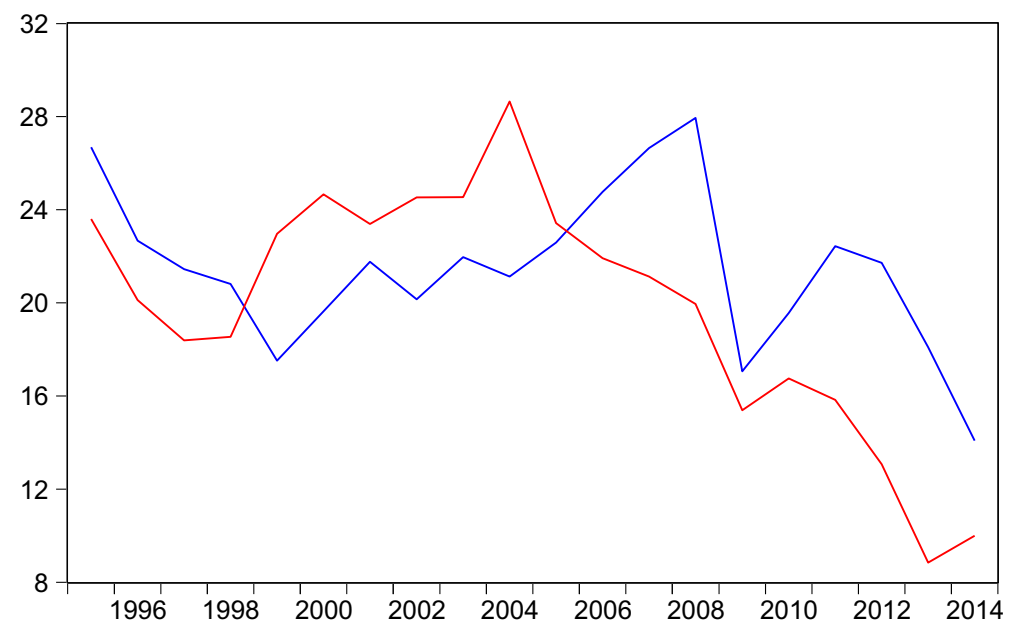

Figure 5: $S / Y$ and $I / Y$ in Ukraine

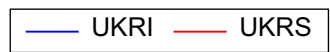

Fig. $5 \mathrm{~S} / \mathrm{Y}$ and $\mathrm{I} / \mathrm{Y}$ in Ukraine

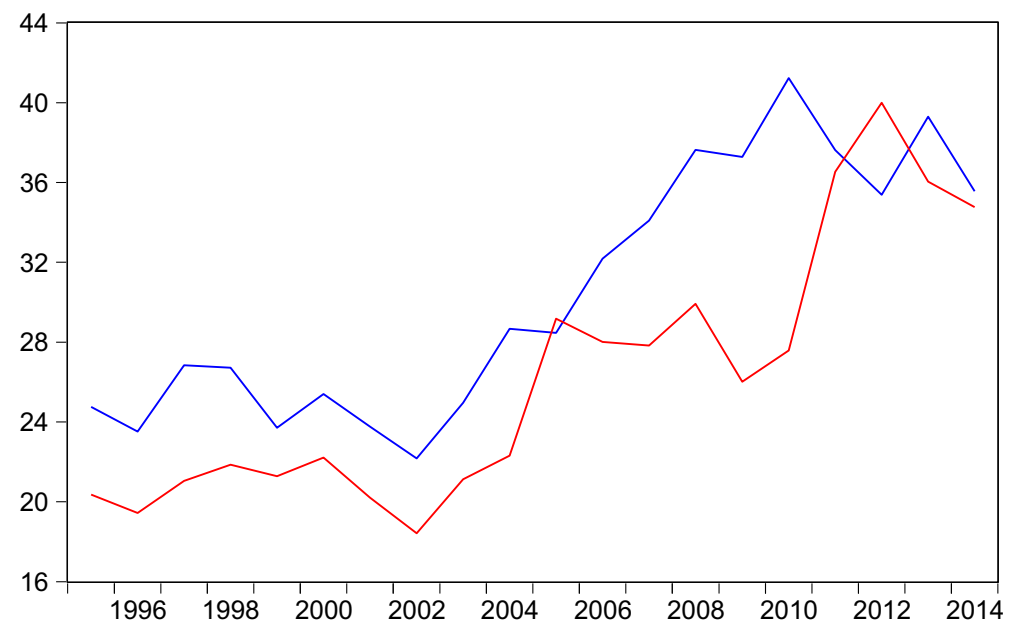

Figure 6: $S / Y$ and $I / Y$ in Belarus

$$
- \text { BLRI } \longrightarrow \text { BLRS }
$$

Fig. $6 \mathrm{~S} / \mathrm{Y}$ and $\mathrm{I} / \mathrm{Y}$ in Belarus 


\section{Appendix 2}

Sample. The annual data (1995-2014) for the following economies are used: Estonia, Latvia, Lithuania, Ukraine, Belarus, and Russian Federation.

Definition of variables. Investment (INV) is the ratio of gross domestic investment to GDP (I/Y) and saving (SAV) is the ratio of gross domestic saving to GDP (S/Y).

Source of data. The data are downloaded from the World Bank's World Development Indicators.

\section{Appendix 3}

\section{Cross-sectional dependence tests}

Breusch and Pagan's (1980) LM test has been used in many empirical studies to test cross-sectional dependency. LM statistics can be calculated using the following panel model:

$$
y_{i t}=\alpha_{i}+\beta_{i}^{\circ} x_{i t}+\mu_{i t}, \quad i=1,2, \ldots, N \quad t=1,2, \ldots, T,
$$

where $i$ is the cross-section dimension, $t$ is the time dimension, $x_{i \mathrm{t}}$ is $k \times 1$ vector of explanatory variables while $\alpha_{i}$ and $\beta_{i}$ are the individual intercepts and slope coefficients that are allowed to differ across states. In the LM test, the null hypothesis of no crosssectional dependence $H_{0}: \operatorname{Cov}\left(\mu_{\mathrm{it}}, \mu_{\mathrm{j} t}\right)=0$ for all $t$ and $i \neq j$ is tested against the alternative hypothesis of cross-sectional dependence $H_{1}: \operatorname{Cov}\left(\mu_{\mathrm{it}}, \mu_{\mathrm{j} t}\right) \neq 0$ for at least one pair of $i \neq j$. For testing the null hypothesis, Breusch and Pagan (1980) developed the following test:

$$
C D_{B P}=T \sum_{i=1}^{N-1} \sum_{j=i+1}^{N} \stackrel{\wedge 2}{\rho},
$$

where $\stackrel{\wedge}{\rho}_{i j}^{2}$ is the estimated correlation coefficient among the residuals obtained from individual OLS estimation of Eq. (6). Under the null hypothesis, the LM statistic has an asymptotic chi-square distribution with $N(N-1) / 2$ degrees of freedom. Pesaran (2004) proposes that the LM test is only valid when $N$ is relatively small and $T$ is sufficiently large. To overcoming this problem, Pesaran (2004) introduces the following LM statistic for the cross-section dependency test:

$$
C D_{p}=\sqrt{\frac{1}{N(N-1)}} \sum_{i=1}^{N-1} \sum_{j=i+1}^{N}(T \underset{i j}{\stackrel{\wedge}{\rho}-1}),
$$

However, Pesaran et al. (2008) state that while the population average pair-wise correlations are zero, the CD test will have less power. Therefore, they proposed a biasadjusted test that is a modified version of the LM test by using the exact mean and variance of the LM statistic. The bias-adjusted LM statistic is calculated as follows: 


$$
L M_{a d j}=\sqrt{\frac{2 T}{N(N-1)} \sum_{i=1}^{N-1} \sum_{j=i+1}^{N}{ }_{i j} \frac{(T-k) \stackrel{\wedge}{\rho}{ }_{i j}^{2}-u_{T_{i j}}}{\sqrt{v_{T_{i j}}^{2}}}},
$$

where $u_{T i j}$ and $v_{T i j}^{2}$ are the exact mean and variance of $(T-k) \underset{i j}{\stackrel{\wedge}{\rho}}$, which are provided in Pesaran et al. (2008). Under the null hypothesis of no cross-sectional dependence with $T \rightarrow \infty$ first followed by $N \rightarrow \infty$, the results of this test follow an asymptotic standard normal distribution.

\section{Slope homogeneity tests}

In order to relax the assumption of homoscedasticity in the F-test, Swamy (1970) developed the slope homogeneity test that examines the dispersion of individual slope estimates from a suitable pooled estimator. Pesaran and Yamagata (2008) state that both the F-test and Swamy's test require panel data models where $\mathrm{N}$ is relatively small compared to $T$. To overcome this problem, they proposed a standardized version of Swamy's test (the socalled $\Delta^{\sim}$ test) for testing slope homogeneity in large panels. The $\Delta^{\sim}$ test is valid when $(N$, $T) \rightarrow \infty$ without any restrictions on the relative expansion rates of $N$ and $T$ when the error terms are normally distributed. Pesaran and Yamagata (2008) then develop the following standardized dispersion statistic:

$$
\bar{\Delta}=\sqrt{N}\left(\frac{N^{-1} S^{\approx}-k}{\sqrt{2 k}}\right),
$$

where $S$ is Swamy's statistic. Under the null hypothesis with the condition of $(N, T) \rightarrow \infty$ and when the error terms are normally distributed, the $\Delta^{\sim}$ test has an asymptotic standard normal distribution. The small sample properties of the $\Delta^{\sim}$ test can be improved when there are normally distributed errors by using the following mean and variance bias adjusted version:

$$
\bar{\Delta}_{a d j}=\sqrt{N}\left(\frac{N^{-1} S^{\approx}-E\left(z_{i t}^{\approx}\right)}{\sqrt{\operatorname{var}\left(z_{i t}^{\tilde{\tau}}\right)}}\right),
$$

where $E\left(z_{i t}^{\approx}\right)=k, \operatorname{var}\left(z_{i t}^{\approx}\right)=2 k(T-k-1) /(T+1)$.

Open Access This article is distributed under the terms of the Creative Commons Attribution 4.0 International License (http://creativecommons.org/licenses/by/4.0/), which permits unrestricted use, distribution, and reproduction in any medium, provided you give appropriate credit to the original author(s) and the source, provide a link to the Creative Commons license, and indicate if changes were made.

\section{References}

Backus DK, Kehoe PJ, Kydland FE (1992) International real business cycles. J Polit Econ 100:745-775

Bahmani-Oskooee M, Chakrabarti A (2005) Openness, size, and the saving-investment relationship. Econ Syst 29:283-293

Bahmani-Oskooee M, Chang T, Wu T (2014) Revisiting purchasing power parity in African countries: panel stationary test with sharp and smooth breaks. Appl Financ Econ 24:1429-1438

Bai Y, Zhang J (2010) Solving the Feldstein-Horioka puzzle with financial frictions. Econometrica 78:603-632 Baxter M, Crucini MJ (1993) Explaining saving-investment correlations. Am Econ Rev 83:416-436

Breusch TS, Pagan AR (1980) The Lagrange multiplier test and its applications to model specification in econometrics. Rev Econ Stud 47(1):239-253

Chang Y, Smith R (2014) Feldstein-Horioka puzzles. Eur Econ Rev 72:98-112

Chu K (2012) The Feldstein-Horioka puzzle and spurious ratio correlation. J Int Money Financ 31:292-309 
Coakley J, Kulasi F, Smith R (1996) Current account solvency and the Feldstein-Horioka puzzle. Economic Journal 106:620-627

Cooper WH (2009) Russia's economic performance and policies and their implications for the United. Congressional research service, June

Dooley MP, Frankel J, Mathieson DJ (1987) International capital mobility- what do saving-investment correlations tell us? IMF staff papers, September, 34. International Monetary Fund, Washington, DC, pp 503-530

Eiriksson AA (2011) The saving-investment correlation and origins of productivity shocks. Japan and the World Economy 23(2011):40-47

European Commission (2009) Taxation trends in the European Union, DG TAXUD. http://ec.europa.eu/taxation customs/resources/documents/taxation/gen_info/economic_analysis/tax_structures/2009/2009_full_text_en.pdf

European Commission (2010) Cross-country study economic policy challenges in the Baltics. Occasional paper 58

European Commission (2015) European economic forecast. European Economy, no. 2/2015

Feldstein M, Bachetta P (1991) National saving and international investment. In: Bernheim D, Shoven J (eds) National Saving and economic performance. Univ. of Chicago Press, Chicago, pp 201-226

Feldstein M, Horioka C (1980) Domestic savings and international capital flows. Econ J 90:314-329

Frankel JA (1986) International capital mobility and crowding-out in the US economy: imperfect integration of financial markets or of goods markets? In: Hafer RW (ed) How open is the US economy? Lexington Books, Federal Reserve Bank of St. Louis, Lexington, pp 33-67

Glick R, Rogoff K (1995) Global versus country-specific productivity shocks and the current account. J Monet Econ 35:159-192

Grigonytė D (2010) FDI and structural reforms in the Baltic states economic analysis from the European Commission's Directorate-General for Economic and Financial Affairs 7, no. 5

Harberger A (1980) Vignettes on the world capital market. Am Econ Rev 70:331-337

Jansen WJ (1996) The Feldstein-Horioka test of international capital mobility: is it feasible? IMF working paper, 96/100. International Monetary Fund, Washington, DC

Kónya L (2006) Exports and growth: granger causality analysis on OECD countries with a panel data approach. Econ Model 23:978-992

KPMG (2011) Investment in Belarus. KPMG report. Minsk, July

KPMG (2013) Investing in Russia: An overview of the current investment climate in Russia. KPMG report. April

Leachman LL (1990) Causality between investment and saving rates: inferences for the international mobility of capital among OECD countries. Int Econ J 4(3):23-39

Levy D (1995) Investment-saving co-movement under endogenous fiscal policy. Open Econ Rev 6(3):237-254

Murphy R (1984) Capital mobility and the relationship between saving and investment rates in OECD countries. J Int Money Financ 3:327-342

Nell KS, Santos LD (2008) The Feldstein-Horioka hypothesis versus the long-run solvency constraint model: a critical assessment. Econ Lett 98:66-70

Obstfeld M, Rogoff K (2000) The Six Major Puzzles in International Macroeconomics: Is There a Common Cause? NBER Working Paper, W7777, Cambridge

Ogutcu M (2002) Attracting foreign direct investment for Russia's modernization battling against the odds. OECD-Russia Investment Roundtable, Saint Petersburg

Pelgrin F, Schich S (2008) International capital mobility: what do national saving-investment dynamics tell us? J Int Money Financ 27:331-344

Pesaran MH (2004) General diagnostic tests for cross section dependence in panels. Cambridge Working Papers in Economics No. 0435. Faculty of Economics, University of Cambridge

Pesaran MH, Yamagata T (2008) Testing slope homogeneity in large panels. J Econ 142:50-93

Pesaran MH, Ullah A, Yamagata T (2008) A bias-adjusted LM test of error cross-section independence. Econometrics Journal 11:105-127

Rasin A (1993) The dynamic-optimizing approach to the current account: Theory and evidence. NBER Working Paper, W4334. National Bureau of Economic Research, Cambridge

Sinn S (1992) Saving-investment correlations and capital mobility: on the evidence from annual data. Economic Journal 102:1162-1170

Summers LH (1982) Tax policy, the rate of return and savings. NBER Working Paper, W995. National Bureau of Economic Research, Cambridge

Swamy PAVB (1970) Efficient inference in a random coefficient regression model. Econometrica 38:311-323

The Economist (2014) Why is Ukraine's economy in such a mess? March, London. https:/www.economist. com/blogs/freeexchange/2014/03/ukraine-and-russia

Tsong CC, Lee CF (2011) Asymmetric inflation dynamics evidence from quantile regression analysis. J Macroecon 33:668-680

UNCTAD (2016) World Investment Report. Geneva 